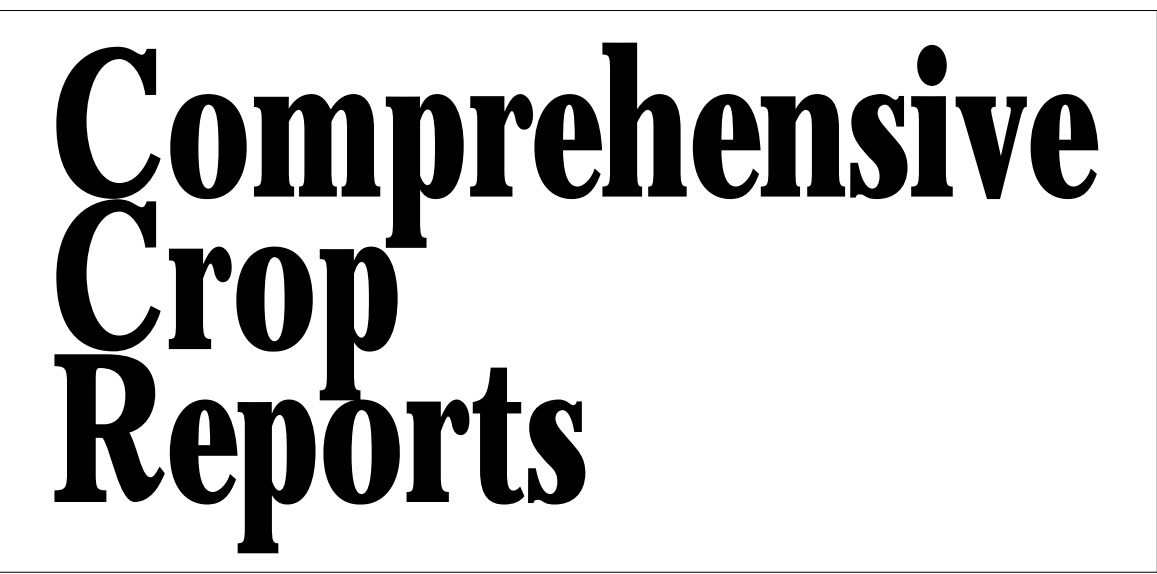

\section{Salvia: An Old Standby and Promising Newcomer}

\author{
Louis B. Anella ${ }^{1}$
}

AdDitional InDEX words. sage, bedding plant, crop production, floriculture, clary

alvia L. is a large genus comprised of about 900 species of annual, biennial, or perennial herbs, subshrubs, or shrubs (G riffiths, 1994). O ver 140 species are used as garden plants, culinary and medicinal herbs, cut flowers, and for habitat gardening (Griffiths, 1994). Salvia, the $L$ atin name for this group of plants, also functions as a common name and is presumably derived from salvus meaning well, safe, or sound; referring to the plant'smedicinal uses. The common name for most species in the genus Salvia is sage and is usually preceded by at least onemodifier, such as common sage (S. officinalis L.), or

$\overline{\text { Approved for publication by the director, O klahoma }}$ Agricultural Experiment Station. This research was supported under project O KL 02441. Theinformation given in this publication is for educational purposes only. M ention of a trademark, proprietary product, or vendor does not constitute a guarantee or warranty of the product, nor does it imply approval or disapproval to the exclusion of other products or vendors that may also be suitable. The cost of publishing this paper was defrayed in part by page charges. U nder postal regulations, this paper therefore must be hereby marked advertisement solely to indicate this fact.

${ }^{1}$ Assistant professor, D epartment of $\mathrm{H}$ orticulture and L andscape Architecture, O klahoma State U niversity, 360 Agricultural H all, Stillwater, OK 74078. mexican bush sage(S. leucantha Cav.). A few salvia species are known as clary (S. sclarea L.), meadow clary (S. pratensis L.), and wild clary (S. verbenaca L.) and at least two have neither clary nor sage in the common name: jupiter's-distaff(S. glutinosa L.), and cancerweed (S. Iyrata L.) (Liberty $\mathrm{H}$ yde Bailey $\mathrm{H}$ ortorium, 1976). Clary also hasits linguistic roots in theplant's usage; S. sclarea was used for afflictions of the eye and therefore called cleareye or clary (Stearn, 1992).

Salvia is the largest genus in the family L abiatae (L amiaceae), the mint family (Clebsch, 1997; G riffiths, 1994). Like many members of the mint family, salvias are characterized by square stems (cross section), opposite leaves, flowers formed in false whorls (verticillasters), and aromatic foliage. Salvia flowers are disposed in terminal or axillary racemes, spikes, panicles, or cymes. The calyx has two lips, the lower deeply two-toothed, the upper three-toothed. The corolla is also two-lipped, the upper hooded, erect or plane and the lower spreading with three lobes. Salvia is also characterized by having two stamens, included or excerted, and fruit containing four ovoid, three-angled nutlets (Griffiths, 1994; Liberty H yde Bailey H ortorium, 1976). H ummingbirds, bees, bumblebees, and bee-flies harvest nectar from salvias and thereby act as pollinators (Boring et al., 1995).

Some species, such as scarlet sage (S. splendensSell ex Roem. \& Schult.), are perennial herbsin their native habitat but are used as annuals in temperate climates. Additionally, mealycup sage (S. farinacea Benth.) is a perennial herb in its native $M$ exico and southern Texas but is grown as an annual throughout the more temperate regions of the U nited States. Such plants are sometimes referred to as tender perennials or as half hardy perennials (Armitage, 1989).

Although of cosmopolitan distribution, salvias are generally characterized as growing in dry or stony soils (Liberty $\mathrm{H}$ yde Bailey $\mathrm{H}$ ortorium, 1976). O ne notable exception is bog sage (S. uliginosa Benth.), which is native to wet soils in Brazil, $U$ raguay, and Argentina (Griffiths, 1994).

Although about 140 species are in cultivation, only a few salvias are commonly found in commerce and gardens. Common sage is a culinary herb grown for commercial herb production, home kitchen use, and as decorative foliage in the garden. The chromosome number for this species is $2 n=14$ (Goldblatt and Johnson, 1998). There isan extensiveliterature, mostly from Europe, on the chemical composition, production, and extraction of essential oils from common sage and related species (Serrato$\checkmark$ alenti et al., 1997) but these topics will not be covered in this review.

Scarlet sage, is one of the leading 25 bedding plants. M uch of the literature on ornamental production of salvia focuses on scarlet sage $(2 n=44$, Goldblatt and J ohnson, 1996) and thus many references discuss salvia without distinguishing between species. $M$ ealycup sage $(2 n=18$, Goldblatt and Johnson, 1990), a native of the southwestern U nited States, is used for bedding or in a mixed border. As native plant gardening increasesin popularity, the number of salvia species found in commerce increases but most of the scientific literature has focused on the species mentioned above.

\section{Cultivar development}

Of the ornamental salvias, cultivar development has been most extensive for scarlet sage. N ovartis Seeds (Downers Grove, III.) and PanAmerican Seed Co. (West Chicago, III.) have contributed to cultivar development for this species. D warf cultivars, such as those in the Sizzler series, flower in the pack yet tend to develop leaf scorch and pigment bleaching during high summer temperatures. Cultivars like 'Vista' and 'Empire' may not flower in time for spring sales but are superior garden plants showing greater tolerance of summer heat and sun. Color also affects leaf scorch: purple, burgundy, rose, and red cultivars are scorch resis- 
T able 1. Salvia species and their landscape characteristics (B oring et al., 1995; Clausen and E kstrom, 1989; Clebsch, 1997; G riffiths, 1994; Still, 1994; Wasowski and Wasowski, 1997).

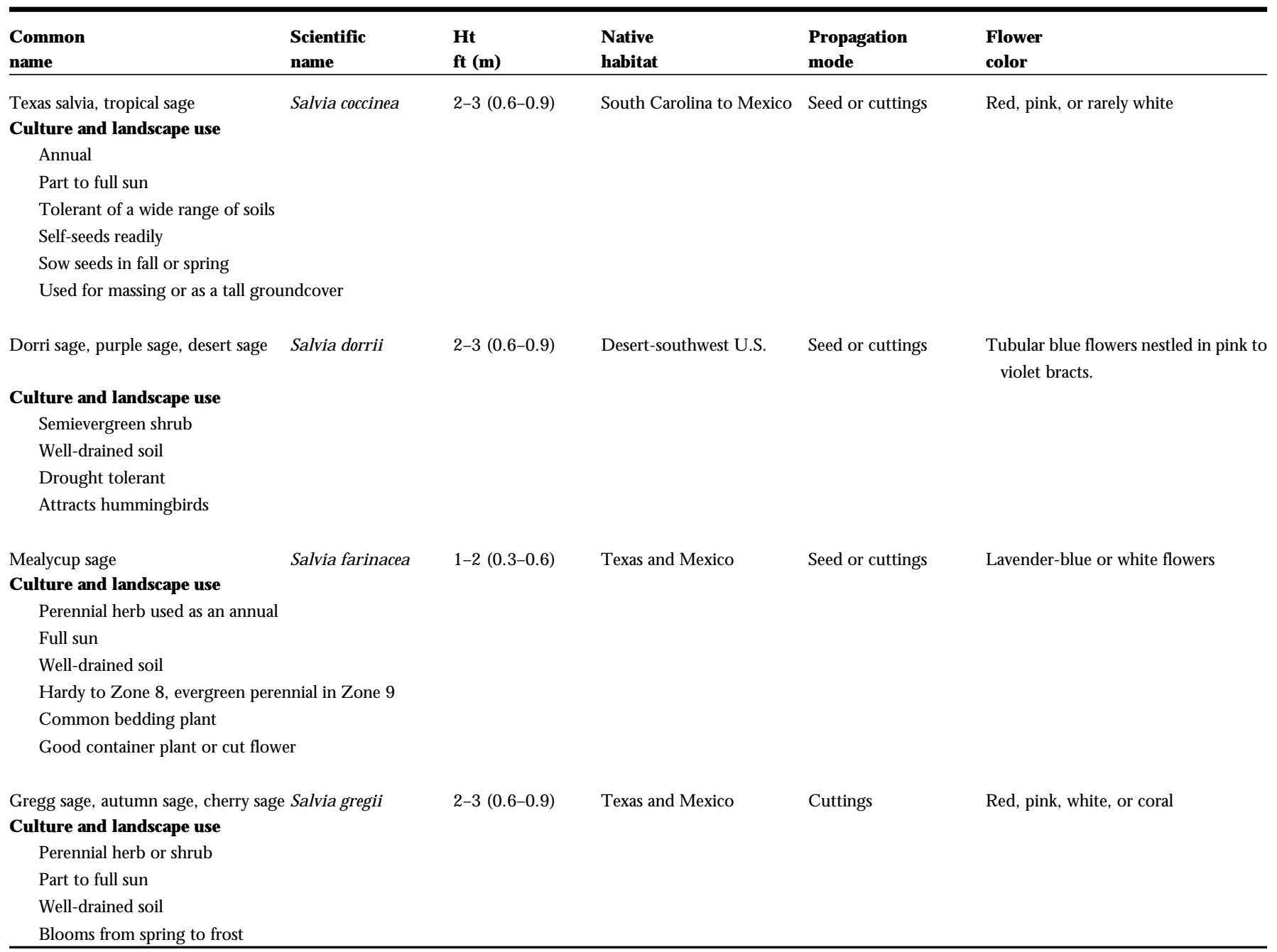

tant, while white (white cultivars of scarlet sagetend to be cream-colored), salmon, and bicolor cultivars tend to develop leaf scorch (Armitage, 1994; J. $\mathrm{N}$ au, personal communication).

\section{Crop PRODUCTION}

Production of scarlet sage requires high light. Supplemental photosynthetic lighting of seedlings accelerates development and limits excessively leggy growth (Armitage, 1994), but photoperiod requirements for flowering are cultivar dependent. Carlson (1978) suggested three categories for the photoperiod response of scarlet sage cultivars: 1) cultivars that flower faster under short days (facultative short day plants), 2) cultivars that flower in the same length of time under either long or short days (day neutral plants), and 3) cultivars that flower faster under long days (facultative long day plants). O f 44 cultivarsstudied, C arlson found 18 to be quantitative short day, 11 to be day neutral, and 14 to be quantitative long day plants (one cultivar did not flower at all). Recommended photoperiod length for optimum production can vary by cultivar and with temperature: Weiler (1972) and Weiler and Lai (1973) reported 'St. J ohn'sFire' to be day neutral when grown at either $75^{\circ} \mathrm{F}\left(24^{\circ} \mathrm{C}\right)$ or $60^{\circ} \mathrm{F}$ $\left(16^{\circ} \mathrm{C}\right.$ ) while Carlson (1978) listed it as a long day plant when grown at 70 to $75^{\circ} \mathrm{F}\left(21\right.$ to $24^{\circ} \mathrm{C}$ ). 'St. J ohn'sFire' had an increased responseto daylength at $75^{\circ} \mathrm{F}\left(24^{\circ} \mathrm{C}\right)$ over $60^{\circ} \mathrm{F}\left(16^{\circ} \mathrm{C}\right)$ indicating that temperature may account for differences in reported photoperiod requirements(Weiler, 1972).

M exican bush sage is a short day plant that flowersin autumn (Armitage, 1993). This perennial herb, native to $M$ exico and tropical America, requires long days and warm temperatures for vegetative growth and short days and warm temperatures for flower initia- tion and development. M exican bush sage can be grown as a cut flower in 11 to 15 weeks by providing 3 to 5 weeks of long daysfollowed by 8 to 10 weeks of short days (Armitage, 1993).

Scarlet sage, texas salvia ( $S$. coccinea Juss. ex Murray.), and mealycup sage should be grown at 57 to $59^{\circ} \mathrm{F}$ (14 to $\left.15^{\circ} \mathrm{C}\right)(\mathrm{N} \mathrm{au}, 1993)$, whilescarlet sage grows best with night temperatures of 55 to $59^{\circ} \mathrm{F}$ ( 13 to 15 ${ }^{\circ} \mathrm{C}$ ) and day temperatures of 70 to 75 ${ }^{\circ} \mathrm{F}\left(21\right.$ to $\left.24^{\circ} \mathrm{C}\right)$ (Armitage, 1994). Scarlet sage responded strongly to a difference between day and night temperatures (DIF), a response that can be used to regulate plant height (Barrett and Erwin, 1994). Internode length was greatest for scarlet sage with a cooler night than daytemperature ( $D$ I $F$ $\left.=+6^{\circ} \mathrm{F}\left[+3.3^{\circ} \mathrm{C}\right]\right)$, was intermediate with a constant temperature, and shortest with a higher night than day temperature $\left(\mathrm{DIF}=-5{ }^{\circ} \mathrm{F}\left[-2.8^{\circ} \mathrm{C}\right]\right)$. $\mathrm{U}$ sing temperature to reduce intern- 
T able 1. Continued.

\begin{tabular}{|c|c|c|c|c|c|}
\hline $\begin{array}{l}\text { Common } \\
\text { name }\end{array}$ & $\begin{array}{l}\text { Scientific } \\
\text { name }\end{array}$ & $\begin{array}{l}\mathrm{Ht} \\
\mathrm{ft}(\mathrm{m})\end{array}$ & $\begin{array}{l}N \text { ative } \\
\text { habitat }\end{array}$ & $\begin{array}{l}\text { Propagation } \\
\text { mode }\end{array}$ & $\begin{array}{l}\text { Flower } \\
\text { color }\end{array}$ \\
\hline M exican bush sage & Salvia leucantha & $4(1.2)$ & M exico & Cuttings or division & $\begin{array}{l}\text { White or purple flowers surrounded by } \\
\text { purple to lavender-blue calyces }\end{array}$ \\
\hline \multicolumn{6}{|l|}{ C ulture and landscape use } \\
\hline \multicolumn{6}{|c|}{ Perennial herb or shrub used as an annual } \\
\hline \multicolumn{6}{|l|}{ Full sun } \\
\hline \multicolumn{6}{|l|}{ Good cut flower } \\
\hline Common sage, garden sage & Salvia officinalis & $1-2(0.3-0.6)$ & M editerranean region & Cuttings or division & Lilac-blue \\
\hline \multicolumn{6}{|l|}{ C ulture and landscape use } \\
\hline \multicolumn{6}{|l|}{ Perennial subshrub } \\
\hline \multicolumn{6}{|l|}{ Full sun } \\
\hline Scarlet sage, red salvia & Salvia splendens & $0.5-2.5(0.2-0.8)$ & Brazil & Seed & Scarlet, purple, lavender, red, cream, or \\
\hline \multicolumn{6}{|c|}{ C ulture and landscape use } \\
\hline \multicolumn{6}{|c|}{ Perennial or annual herb used as an annual } \\
\hline \multicolumn{6}{|c|}{ Full sun } \\
\hline \multicolumn{6}{|l|}{ Well-drained soil } \\
\hline \multicolumn{6}{|l|}{ Common bedding plant } \\
\hline Perennial salvia & Salvia ×superba & $2-3(0.6-0.9)$ & Of garden origin & Cuttings and division & Violet or purple \\
\hline \multicolumn{6}{|l|}{ C ulture and landscape use } \\
\hline \multicolumn{6}{|l|}{ Perennial herb } \\
\hline
\end{tabular}

ode length is most effective if the temperaturedrop (DROP) israpid, occurs at sunrise, and during high light intensity.

Although scarlet sagecannot withstand freezing temperatures, optimum temperature for storage and transport of plugs ranges from 45 to $55^{\circ} \mathrm{F}$ ( 7 to $13^{\circ} \mathrm{C}$ ) (H eins et al., 1994); however, Armitage (1994) cautions that reddening of foliage may occur below 50 ${ }^{\circ} \mathrm{F}\left(10^{\circ} \mathrm{C}\right)$. Perennial salvia (Salvia ×superba Stapf.), an herbaceous perennial of garden origin, isa cold hardy plant able to withstand root medium temperatures to $-14{ }^{\circ} \mathrm{F}\left(-10^{\circ} \mathrm{C}\right)$; however, regrowth was limited when root medium temperatures were reduced to $-10^{\circ} \mathrm{F}\left(-12^{\circ} \mathrm{C}\right)$ indicating a well-defined low-temperature threshold for this species (Iles and Agnew, 1993).

\section{Propagation}

Scarlet sage isproduced from seed
(Armitage, 1994), while perennial species may be produced from either seed or cuttings. A utumn sage (S. greggii A. Gray.) does not remain true to type when grown from seed, thus named cultivars should be propagated from cuttings. Certain cultivars of mealycup sage come true from seed and therefore may be propagated by either method (Clebsch, 1997). Salvia seeds should not be stored for greater than one year sincethey lose not only viability but seedlings may have reduced vigor (D ole and Wilkins, 1999).

Germination of scarlet sage ' $\mathrm{R}$ ed $\mathrm{H}$ ot Sally' seed was $0 \%$ at $\mathrm{pH} 4.5$ and $5.0,44 \%$ at 5.5 , and $70 \%$ at 7.0 and 7.5 when germinated on filter paper (Shoemaker and C arlson, 1990). H owever, when seed were placed in perlite of varying $\mathrm{pH}$, germination ranged from 60 to $83 \%$ with no significant differences among the treatments indicating that $\mathrm{pH}$ may not be an important factor when germinating salvia seeds in a growing media. Germination also failed after scarlet sage 'R ed H ot Sally' seeds were stored at $77^{\circ} \mathrm{F}\left(25^{\circ} \mathrm{C}\right)$ and $75 \%$ relative humidity for 12 months (Carpenter et al., 1995). O ptimal germination occurred when seed was stored at a relative humidity between 11 and $32 \%$ regardless of temperature $\left(41,59\right.$, or $77^{\circ} \mathrm{F}\left[5,15\right.$, or $\left.\left.25^{\circ} \mathrm{C}\right]\right)$ but seed storage is recommended below $59^{\circ} \mathrm{F}\left(15^{\circ} \mathrm{C}\right)$ (C arpenter et al., 1995).

Temperature optima for germination are 75 to $77^{\circ} \mathrm{F}\left(24\right.$ to $25^{\circ} \mathrm{C}$ ) for scarlet sage and mealycup sage, 70 to $79{ }^{\circ} \mathrm{F}\left(21\right.$ to $\left.26^{\circ} \mathrm{C}\right)$ for texas salvia, 70 ${ }^{\circ} \mathrm{F}\left(21^{\circ} \mathrm{C}\right)$ for common sage, and 72 ${ }^{\circ} \mathrm{F}\left(22^{\circ} \mathrm{C}\right.$ ) for perennial salvia ( $\mathrm{N}$ au, 1993). Texas salvia, scarlet sage, and mealycup sage require light for germination while common sagegerminates best when covered and perennial salvia may be grown under either condition ( $\mathrm{Nau}, 1993$ ).

Postgermination night temperatures for the above species range from 
55 to $61^{\circ} \mathrm{F}\left(13\right.$ to $\left.16^{\circ} \mathrm{C}\right)(\mathrm{N}$ au, 1993) and Armitage (1994) recommended day temperatures of 70 to $72^{\circ} \mathrm{F}$ ( 21 to $\left.22{ }^{\circ} \mathrm{C}\right)$. Scarlet sage requires 5 to 6 months from sowing to flowering in a 4-inch (10-cm) pot (Armitage, 1994) and mealycup sage reachesa marketable size in 5 months from seed in a 1-gal (3.8-L) container (Knowles et al., 1993).

I n vitro propagation hasbeen used successfully for mexican bush sage (H osoki and Tahara, 1993). Shoots 1 inch $(2.5 \mathrm{~cm})$ long rooted well when transferred to a basal medium with or without IBA and shoot counts increased with increasing BA concentration. Since high BA concentrations [ 1 ppm $\left(\mathrm{mg} \cdot \mathrm{L}^{-1}\right)$ ] decreased shoot length and caused vitrification, H osoki and T amara (1993) recommended 0.1 ppm $B A$ be added to obtain the maximum number of normal shoots. Plantlets were successfully transferred to a sandy loam and bark mix under greenhouse conditions.

\section{Nutrition}

Plug production of scarlet sage is common. Plugs should be fertilized with 50 to 75 ppm N (potassium nitrate) at plug stages two and three and fertilized with 100 to 150 ppm N complete fertilizer once transplanted (Armitage, 19994). M edium electrical conductivity should be maintained at $0.5 \mathrm{dS} \cdot \mathrm{m}^{-1}$ during stages 1 and 2 and can be raised to $1.5 \mathrm{dS} \cdot \mathrm{m}^{-1}$ in stage 4 (Koranski et al., 1996). When ammonium levels exceed 10 ppm, a dark green cast occurs on immature leaves with thick, protruded veins. Therefore, it is important to use fertilizers low in ammonium during early stages of plug production. Similarly, additionsof so dium chloride $(\mathrm{N} \mathrm{aCl})$ caused leaf abscission, slowed growth, lowered leaf K concentration, and increased leaf thickness in seedlings of scarlet sage 'Flare Path' (I brahim et al., 1991). Root and shoot weights were significantly lower at $30 \mathrm{~mm} \mathrm{~N} \mathrm{aCl}$ and total leaf abscission occurred at $60 \mathrm{~mm}$.

A positive linear relationship between shoot nitrogen concentration and shoot dry mass occurred for scarlet sage 'T op Red' but no significant effect was indicated for phosphorous or potassium (van lersel et al., 1998). Nor were significant differences in shoot growth observed at differing $P$ and $\mathrm{K}$ fertilizer rates; however, $\mathrm{P}$ and $\mathrm{K}$ concentrations increased in leaf tissue as fertilizer levels increased suggesting luxury consumption of these nutrients. $O$ ver watering, low calcium, high calcium-inhibiting magnesium, low phosphorus, or low magnesium can all lead to poor root and root hair development in scarlet sage (Koranski et al., 1996). For high-quality salvia plants, the optimum leaf tissue nutrient levels are (in percent) $\mathrm{N}, 3.0$ to $4.5 ; \mathrm{P}, 0.3$ to $0.7 ; \mathrm{K}, 3.5$ to $5.0 ; \mathrm{Ca}, 1.5$ to 2.5 ; and $\mathrm{M} \mathrm{g}, 0.3$ to 0.6 (values based on most recent fully developed leaf) ( $\mathrm{N}$ elson, 1994).

$M$ ealycup sage had greater shoot growth in a bark/ sand mixture after 21 weeks than in a perlite/ vermiculite mixture (Knowles et al., 1993). Shoot growth was maximal in the bark/ sand mixture with either weekly fertigation at $100 \mathrm{ppm} \mathrm{N}$ (as ammonium nitrate, $34 \mathrm{~N}-0 \mathrm{P}-0 \mathrm{~K}$ ) or preplant incorporation of $3 \mathrm{lb} / \operatorname{yard}^{3}\left(2 \mathrm{~kg} \cdot \mathrm{m}^{-3}\right) \mathrm{N}$ (as O smocote, 39N-OP-OK, The Scotts Company, Columbus, O hio). Dry weights did not significantly increase when these levels were exceeded and higher rates of $N$ resulted in leggy plants with excessive plant succulence.

Although $\mathrm{K}$ concentration does not appear to be important for the production of scarlet sage, increased $\mathrm{K}$ concentrations may aid in the postproduction quality of plants. M oisture stress conditioning, lowering greenhousetemperatures, and increasing $\mathrm{K}$ fertilization rates were shown to reduce transpirational water loss while allowing plants to maintain photosynthesis at lower leaf water potentials (Eakes et al., 1991a, 1991b). These treatmentsmay maintain plant appearance during the moisture stress often associated with transport and display of plants in a retail setting; however, fertilizing with $\mathrm{K}$ at $600 \mathrm{ppm}$ also resulted in small plant size compared with 300 ppm.

\section{Height control}

Plant sizecan becontrolled during production with theuse of growth regulators, DIF, soil volume, and cultivar selection (van lersel, 1997; Armitage, 1994; I ncrocci et al., 1994; H iguchi et al., 1987). Scarlet sage cultivarsare generally divided into three groups: dwarf (8 to 12 inch [20 to $30 \mathrm{~cm}$ ]), medium (12 to 16 inch [ 30 to $40 \mathrm{~cm}$ ]), and tall (>16 inch [40cm]) (Armitage, 1994). Early flower production isrelated to size with the dwarf cultivarstending to flower earlier ( $\mathrm{J}$. $\mathrm{Nau}$, personal communica- tion). I ncreasing container sizeincreased plant size, lateral growth, and plant quality and decreased time to flowering (van lersel, 1997). Thus transplanting plugs early may reduce the production duration of salvia.

Increasing greenhouse temperatures 11 to $14{ }^{\circ} \mathrm{F}\left(6\right.$ to $8{ }^{\circ} \mathrm{C}$ ) above ambient ( 86 to $100{ }^{\circ} \mathrm{F}$ [ 30 to $38^{\circ} \mathrm{C}$ ]) retarded primary shoot growth, increased lateral shoot growth, percentage offlowering shoots, and mean length of inflorescence (H iguchi et al., 1987). Filtering light through copper sulfate $\left(\mathrm{CuSO}_{4}\right)$ hasalso been tested asa means of reducing growth. Incrocci et al. (1994) compared the height of scarlet sage grown under water-filled polycarbonate panels (control) and panelsfilled with a $\mathrm{CuSO}_{4}$ solution. They reported no reduction in height for scarlet sage but reported a 2-week delay in flowering for plants grown under the $\mathrm{CuSO}_{4}$ filters.

Chemical control of height has proven effective for scarlet sage and mealycup sage. D oleand Wilkins(1999) listed amcymidol, chlormequat chloride, daminozide, and ethephon as effective on salvia and paclobutrazol and uniconazole asmost effective. Armitage (1994) recommended two applications of 5000 ppm daminozideor two to four applications of 750 to $1000 \mathrm{ppm}$ chlormequat for height control of scarlet sage.

U niconazole was more effective than either pacl obutrazol or daminozide in reducing the height growth of indigo spires salvia (S. 'Indigo Spires') (Rodrigueset al., 1993). U nrooted cuttingswereeither soaked for $24 \mathrm{~h}$, dipped for $3 \mathrm{~s}$, sprayed, or sprayed and then resprayed $18 \mathrm{~d}$ later with various levels of growth regulators. The $24 \mathrm{~h}$ soak and two sprays with $50 \mathrm{ppm}$ uniconazole were most effective at reducing plant height. These treatments also reduced the number of flower spikes from 11 (control) to 5 but theauthorssuggested that the plants were still commercially viable. The treatment effects were short lived (less than 3 weeks) indicating that application of growth regulatorsduring production would not affect garden performance or that repeated applications would be necessary if continued growth retardation were desired for plants in the landscape.

\section{Pests and diseases}

In the greenhouse, salvia is susceptible to many common disease and in- 
sect problems, including aphids (M yzus persicaeSulzer and other species), whiteflies (Trialeurodes vaporariorum Westwood and Bemisia argentifoli i B ellows \& Perring), spider mites (Tetranychusurticae Koch.), common gray mold (Botryti scinerea P. M icheli ex Pers.), and damping off (Pythium Pringsh., Rhizoctonia DC., and Fusarium Link) (Armitage, 1994). T wo cultivars of scarlet sage, 'Carabiniere Red' and ' $\mathrm{H}$ ot Line Red', were slightly susceptible to root-knot nematodes (Meloidogyne incognita [Kofoid \& White] Chitwood, race 3) when inoculated with 200 eggs/ cell whilemealycup sage 'Rhea' and 'Victoria Blue' were resistant; however, dry weight was not affected for any cultivar nor was dry weight of common sage affected when inoculated (Walker, 1995). A similar studybyM cSorley and Frederick (1994) indicated no gall ling on scarlet sage“ Bonfire' by root-knot nematodes ( $M$. incognita race 1) but did find eggs on a few individual plants inoculated with another species of root-knot nematodes (M. javanica [Treub] Chitwood). Downy mildew (Peronospora lamii $A$. Braun.) and rust (Puccinia salviicola Dietel \& Holw.) have each been reported on varioussal viaspeciesbut salvia is generally free of pest problems in the landscape (M cM illan and G raves, 1994; $\mathrm{H}$ olcomb and Valverde, 1995).

\section{Cut FLowers}

M exican bush sage may be grown in the greenhouse or the field for the specialtycutflower market. Plantsshould be spaced at least 15 inch $(37.5 \mathrm{~cm})$ apart but closer than $3 \mathrm{ft}(90 \mathrm{~cm})$ apart since the large plants will use surrounding plantsfor support (Armitage, 1993; 1987). I nflorescences should be harvested when white flower petals appear on the lower three to four individual flowers. Cut stems last about $7 \mathrm{~d}$ when floral preservatives are used. Individual flowers will shatter if allowed to wilt (Armitage, 1993). M exican bush sage also makes good dried flowers.

\section{Conclusion}

Scarlet sageisbyfar themost widely cultivated species of salvia ( $L$ iberty $\mathrm{H}$ yde BaileyH ortorium, 1976) but hassometimes been maligned by horticulturists. It has been described as having limp, grass green foliage that is ordinary with flowersthat arestrident in color (Clausen and E kstrom, 1989). I n contrast, native perennial species of salvia, such as mealycup sage, have been praised for their drought tolerance and nutrient efficiency making them well adapted for low maintenancelandscapesin thesouth (Knowleset al., 1993). N ativeperennial species are also prized for their wildlife value; hummingbirds and bees seek the flowerswhilebirdseat theseeds(Boring et al., 1995).

Asinterest in nativeplantsincreases, so too will the number of salvia species in cultivation and the need for production information, environmental requirements, and postharvest research on thosespecies (Knowles et al., 1993). Even the most basic information, such as hardiness, has not been investigated for many of the native salvia species as is evidenced by the conflicting hardiness ratings given by gardening books. Since many sal via speciesare nativeto arid and resourcepoor environments, theneed is apparent for further research within this genus. $\mathrm{N}$ ew introductions will require evaluation in different soil types, regions of the country, and in the cultivated landscape.

\section{LiteratuRe CITED}

Armitage, A.M. 1987. The influence of spacing on field-grown perennial crops. H ortScience 22:904-907.

Armitage, A.M . 1989. H erbaceous perennial plants, $A$ treatise on their identification, culture, and garden attributes. Varsity Press, Athens, $\mathrm{Ga}$.

Armitage, A.M . 1993. Specialty cut flowers. Varsity Press/ T imber Press, Portland, O re.

Armitage, A.M. 1994. O rnamental bedding plants. CAB I nternational, Wallingford, United Kingdom.

Barrett, J.E. and J.E. Erwin. 1994. H eight control. In: E.J. H olcomb (ed.). Bedding plants IV. Ball Publ., Batavia, III.

Boring, J.K., E. Glasener, G. Keator, J. Knopf, J. Scott, and S. Wasowski. 1995. $\mathrm{N}$ atural gardening. Time-Life Books, N ew York.

Carlson, W. 1978. Daylength and salvia varieties. Amer. Veg. Grower 26:20-21.

Carpenter, W.J., E.R. O stmark, and J.A. Cornell. 1995. Evaluation of temperature and moisture content during storage on the germination of flowering annual seed. $\mathrm{H}$ ortScience 30:1003-1006.

Clausen, R.R. and N.H. Ekstrom. 1989. Perennials for American gardens. Random H ouse, N ew York.

Clebsch, B. 1997. A book of salvias, sages for every garden. Timber Press, Portland, Ore.

Dole, J.M. and H.F. Wilkins. 1999. Floriculture: Principles and species. PrenticeH all, Inc., U pper Saddle River, N.J .

Eakes, D.J., F.D. Wright, and J.R. Seiler. 1991a. Potassium nutrition and moisture stress tolerance of Salvia. H ortScience 26:422.

Eakes, D.J., F.D. Wright, and J.R. Seiler. 1991b. Water relations of Salvia splendens 'Bonfire' as influenced by potassium nutrition and moisture stress conditioning. J. Amer. Soc. H ort. Sci. 116:712-715.

Goldblatt, P. and D.E. Johnson. 1998. Index to plant chromosome numbers 19941995. M onogr. Syst. Bot. M o. Bot. Garden 69:99.

Goldblatt, P. and D.E. Johnson. 1996. Index to plant chromosome numbers 19921993. M onogr. Syst. Bot. M o. Bot. Garden 58:134.

Goldblatt, P. and D.E. Johnson. 1990. Index to plant chromosome numbers 19861987. M onogr. Syst. Bot. M o. Bot. Garden 30:106.

Griffiths, M. 1994. Index of garden plants. Timber Press, Portland, O re.

H eins, R., N . Lange, T.F. Wallace, J r., and W. Carlson. 1994. Plug storage. Greenhouse grower. Meister Publishing, Willoughby, O hio.

$\mathrm{H}$ iguchi, H., W. Amaki, M. M inami, and S. Suzuki. 1987. Effects of high temperature on lateral shoot growth of salvia and impatiens after pruning. H ortScience 22:618619.

H olcomb, G.E. and R.A. Valverde. 1995. First report of rust on Salvia coccinea in L ouisiana. Plant D is. 79:426 (abstr.).

H osoki, T. and Y. Tahara. 1993. In vitro propagation of Salvia leucantha $\mathrm{Cav}$. $\mathrm{H}$ ortScience 28:226.

I brahim, K.M., and J.C. Collins, and H.A. Collin. 1991. Effects of salinity on growth and ionic composition of Coleusblumei and Salvia splendens. J. H ort. Sci. 66:215-222.

Iles, J .K. and N .H . Agnew. 1993. Responses of five container-grown herbaceous perennial species to laboratory freezing. H ortTechnology 3:192-194.

I ncrocci, L., G. Serra, and B. Lercari. 1994. $\mathrm{H}$ eight control of a bedding plant (Salvia splendensF. Sellow) by copper sulphate filters. Acta H ort. 361:491-493.

Knowles, T.C., B.W. H ipp, and M.A. H egemann. 1993. Container medium and slow-release nitrogen fertilizer influence growth and quality of Salvia farinacea. $\mathrm{H}$ ortScience 28:623-625. 
Koranski, D ., R. Kessler, M. Khademi, and D. M cN ertney. 1996. Troubleshooting: Diagnose your plug problems. In: D. $\mathrm{H}$ amrick (ed.). Grower talks on plugs II. Ball Publ., Batavia, III.

Liberty Hyde Bailey Hortorium. 1976. $\mathrm{H}$ ortus third: A concise dictionary of plants cultivated in the U nited States and Canada. $3^{\text {rd }}$ ed. M acmillan, N ew York.

M cM illan, Jr., R.T. and W.R. Graves. 1994. First report of downy mildew of Salvia in Florida. Plant D isease 78:317 (abstr.).

M cSorley, R. and J.J. Frederick, 1994. Response of some common annual bedding plants to three species of M doidogyne J. N ematol. 26:773-777.

$\mathrm{N}$ au, J. 1993. Ball culture guide. $2^{\text {nd }}$ ed. Ball Publ. Batavia, III.

N elson, P.V. 1994. Fertilization, p. 151175. In: E.J. H olcomb (ed.). Bedding plants IV. Ball Publ., Batavia, III.

Rodriquez, D., T.D. D avis, J.M. Parsons, and N. Sankhla. 1993. U se of growth retardants in the production of container-grown Salvia farinacea $\times$ longispicata 'Indigo Spires'. Plant Growth Reg. Soc. Amer. Quarterly 21:180-189.

Serrato-Valenti, G., A. Bisio, L. Cornara, and G. Ciarallo. 1997. Structural and histochemical investigation of the glandular trichomes of Salvia aurea L. leaves, and chemical analysis of the essential oil. Ann. Bot. 79:329-336.
Shoemaker, C.A. and W.H . C arlson. 1990. $\mathrm{pH}$ affects seed germination of eight bedding plants species. $\mathrm{H}$ ortScience 25:762764.

Stearn, W.T. 1992. Stearn's dictionary of plant names for gardeners. Cassell Publ. Ltd., London.

Still, S.M. 1994. M anual of herbaceous ornamental plants. Stipes Publ. Co., Champaign, III.

Van I ersel, M. 1997. Root restriction effects on growth and development of salvia (Salvia splendens). H ortScience 32:1186-1190.

van lersel, M.W., R.B. Beverly, P.A. Thomas, J.G. Latimer, and H.A. M ills. 1998. Fertilizer effectson the growth of impatiens, petunia, salvia, and vinca plug seedlings. H ortScience 33:678-682.

Walker, J.T. 1995. Garden herbsashostsfor southern root-knot nematode [M eloidogyne incognita (Kofoid \& White) C hitwood, race 3]. H ortScience 30:292-293.

Wasowski, S. and A. Wasowski. 1997. N ative Texas plants: Landscaping region by region. Gulf Pub. C o., H ouston, Texas.

Weiler, T.C. 1972. The variable flowering response of Salvia splendens Sello. to daylength. Amer. Soc. H ort. Sci. 97:355357.

Weiler, T.C. and C.H. Lai. 1973. Critical daylength for inflorescence formation of several cultivars of Salvia splendens Sello. $\mathrm{H}$ ortScience 8:184. 